\title{
Perfil socioeconômico da produção de açaí manejado em comunidades rurais do
}

\section{Município de Igarapé-Miri, Pará}

\author{
Socio-economic profile of açaí production managed in rural communities in the Municipality of \\ Igarapé-Miri, Pará State \\ Perfil socioeconómico de la producción açaí gestionada en comunidades rurales del Municipio de \\ Igarapé-Miri, Estado de Pará
}

Recebido: 31/08/2021 | Revisado: 07/09/2021 | Aceito: 08/09/2021 | Publicado: 11/09/2021

\author{
Hellem Pinheiro Almeida \\ ORCID: https://orcid.org/0000-0003-0653-2457 \\ Universidade do Estado do Pará, Brasil \\ E-mail: hellem.hpa@gmail.com \\ Alfredo Kingo Oyama Homma \\ ORCID: https://orcid.org/0000-0003-0330-9858 \\ Embrapa Amazônia Oriental, Brasil \\ Universidade do Estado do Pará, Brasil \\ E-mail: alfredo.homma@embrapa.br \\ Antônio Jose Elias Amorim de Menezes \\ ORCID: https://orcid.org/0000-0002-3294-5354 \\ Embrapa Amazônia Oriental, Brasil \\ E-mail: antonio.menezes@embrapa.br \\ Gisalda Carvalho Filgueiras \\ ORCID: https://orcid.org/0000-0002-4695-6505 \\ Universidade Federal do Pará, Brasil \\ E-mail: gisalda.filgueiras@gmail.com \\ João Tomé de Farias Neto \\ ORCID: https://orcid.org/0000-0002-0404-3556 \\ Embrapa Amazônia Oriental, Brasil \\ E-mail: joao.farias@embrapa.br
}

\begin{abstract}
Resumo
O açaizeiro (Euterpe oleracea Mart.) é uma palmeira de ocorrência natural em ambiente de várzea do estuário amazônico, de suma importância na alimentação e na geração de renda para os ribeirinhos. A pesquisa analisou a socioeconomia da produção de açaí nas comunidades de Anapú, Caji e Meruú, município de Igarapé-Miri (Pará) por meio da realização de entrevistas com aplicação de 61 questionários semiestruturados juntos aos produtores de açaí, além das explorações de campo com registros fotográficos e coordenadas geográficas, optando por uma amostragem intencional. As famílias coletam $36.139,38 \mathrm{~kg}$ de fruto durante o ano, sendo 61,53\% na safra e 38,47\% na entressafra e apresenta uma produtividade de $3.013,90 \mathrm{~kg} / \mathrm{ha}$. Verificou-se que a maioria dos produtores são do sexo masculino com média de 50 anos de idade, baixo nível de escolaridade, nativos e com renda variando de 1 a 2 salários mínimos mensais. Residências apresentam infraestruturas rústicas e com ausência de esgoto sanitário adequado. No entanto, a pequena parcela de casas de alvenaria e piso de lajota indica o anseio por melhorias.
\end{abstract}

Palavras-chave: Açaí; Manejo; Produção; Estado do Pará; Amazônia.

\begin{abstract}
The assai tree (Euterpe oleracea Mart.) is a palm that occurs naturally in the floodplain environment of the Amazon estuary, which is extremely important in terms of food and income generation for riverside dwellers. The research analyzed the socio-economics of assai production in the communities of Anapú, Caji and Meruú, municipality of Igarapé-Miri (Para State) through interviews with the application of 61 semi-structured questionnaires together with açai producers, in addition to field explorations with photographic records and geographic coordinates, opting for an intentional sampling. The families collect $36,139.38 \mathrm{~kg}$ of fruit during the year, $61.53 \%$ in the harvest and $38.47 \%$ in the off-season, with a productivity of $3,013.90 \mathrm{~kg} / \mathrm{ha}$. It was found that most producers are male with an average of 50 years old, low level of education, native and with income ranging from 1 to 2 minimum wages per month. Residences have rustic infrastructure and lack of adequate sanitary sewage. However, the small portion of masonry houses and tiled floors indicates the desire for improvement.
\end{abstract}

Keywords: Açai; Management; Production; State of Pará; Amazon. 


\begin{abstract}
Resumen
El árbol de açaí (Euterpe oleracea Mart.) es una palmera que se encuentra de forma natural en el entorno de la llanura aluvial del estuario del Amazonas, que es extremadamente importante en términos de generación de alimentos e ingresos para los habitantes de las riberas. La investigación analizó la socioeconomía de la producción de açaí en las comunidades de Anapú, Caji y Meruú, municipio de Igarapé-Miri (Pará) a través de entrevistas con la aplicación de 61 cuestionarios semiestructurados junto a productores de açaí, además de exploraciones de campo con registros fotográficos y coordenadas geográficas, optando por un muestreo intencional. Las familias recolectan $36.139,38 \mathrm{~kg}$ de fruta durante el año, $61,53 \%$ en cosecha y 38,47\% fuera de temporada, con una productividad de $3.013,90 \mathrm{~kg} / \mathrm{ha}$. Se encontró que la mayoría de los productores son hombres con un promedio de 50 años de edad, bajo nivel educativo, nativos y con ingresos que oscilan entre 1 y 2 salarios mínimos mensuales. Las residencias tienen infraestructura rústica y carecen de alcantarillado sanitario adecuado. Sin embargo, la pequeña porción de casas de mampostería y pisos de baldosas indica el deseo de mejora.
\end{abstract}

Palabras clave: Açaí; Gestión; Producción; Estado de Pará; Amazonia.

\title{
1. Introdução
}

O açaizeiro (Euterpe oleracea Mart.), é uma palmeira tropical, amplamente distribuída no estuário amazônico e essencial na alimentação e no fomento da renda familiar de indivíduos que vivem na região amazônica. É uma planta de ocorrência natural em ambiente de várzea do estuário amazônico, como espécie integrante da floresta nativa ou constituindo açaizais (Nogueira; Homma, 1998).

Segundo Araújo e Navegantes-Alves (2015), o aumento da demanda suscitou mudanças no uso desta espécie nativa pelos ribeirinhos, pois o mesmo era destinado à subsistência das famílias locais. Contudo, atualmente, se tornou o principal alimento consumido, assim como a principal fonte de renda. O crescimento do mercado do fruto está ocasionando mudanças na cultura de uso do açaizeiro pelos ribeirinhos das áreas de várzeas, o que provoca alteração na floresta e no uso de outras espécies. Além disso, embora a produção ocasione benefícios financeiros às comunidades ribeirinhas, a dependência econômica exclusiva de um único produto torna-se vulnerável às instabilidades do mercado consumidor e do período da entressafra (Carim et al, 2014).

Essas áreas de várzeas da foz do rio Amazonas são submetidas à inundação diária, decorrentes da ação das marés, resultantes do fluxo e refluxo (enchente e vazante). O fluxo baseia-se no aumento do nível da água, que apresenta duração de 6 horas e 12 minutos até alcançar seu limite máximo (preamar) se mantendo por 7 minutos até começar o refluxo que consiste na redução do nível da água por 6 horas e 12 minutos, também, até atingir seu limite mínimo (baixa-mar) ficando estável por 7 minutos até recomeçar a enchente (Sioli;1991; Homma et al, 2006).

Da perspectiva do potencial econômico, a várzea caracteriza-se por limitações à agricultura em virtude das constantes enchentes produzidas pelas marés. A inserção de práticas agrícolas, inclusive, de palmáceas que possuem a várzea como habitat natural, se adaptando a terrenos úmidos e clima quente e úmido que constituem condições propícias para o seu cultivo, possibilita a produção de açaí, que se transformou no principal produto da várzea do município de Igarapé-Miri (Reis, 2008).

O município de Igarapé-Miri é formado por extensa área de várzeas sujeitas à inundação das marés, em que a população se articula com os rios utilizados como via de transporte, constituindo um fator de integração socioeconômica, bem como reservatório de recursos naturais para o consumo doméstico. A principal atividade econômica da região é o manejo do açaizeiro, portanto, considerado fonte essencial de geração de renda para a maioria da população, onde na época da safra há um giro na movimentação financeira e na entressafra as comunidades passam por dificuldades financeiras, pois é na época do inverno que acontecem as grandes cheias dos rios (lançantes), inviabilizando atividades como a pesca e produção agrícola (Oliveira et al., 2007).

De acordo com Aranha (2015), a fonte de renda de Igarapé-Miri era baseada na exploração de madeira nativa e de cana de açúcar e engenhos. Com o declínio dos engenhos, a produção do açaí que era destinado somente para o consumo, se transformou na principal fonte de renda dos ribeirinhos locais. 
A partir da década de 1990 o açaí passou a ser considerado como fonte de renda para as comunidades ribeirinhas e contribuir para obtenção de bens duráveis. O aumento da demanda do açaí ocasionou mudanças na oferta do produto, influenciando nas variações dos preços do produto, sobretudo na entressafra (Resque, 2012). Portanto, o objetivo do trabalho foi analisar o perfil socioeconômico da produção de açaí em comunidades rurais do município de Igarapé-Miri, Pará.

\section{Material e Métodos}

\section{1 Área de Estudo}

A pesquisa foi realizada nas comunidades de Anapú, Caji e Meruú no município de Igarapé-Miri. A escolha das áreas foi em virtude de as mesmas apresentarem destaque no cenário da produção de açaí.

A escolha dos produtores de açaí foi através da técnica nomeada como "bola de neve", uma forma de amostra não probabilística útil para pesquisar grupos difíceis de serem acessados, estudados e da questão custo, bem como quando não há precisão sobre sua quantidade (Lakatos \& Marconi, 2004; Lakatos \& Marconi, 2010).

\subsection{Localização}

O município de Igarapé- Miri, Pará está localizado na mesorregião do Nordeste Paraense (Baixo Tocantins), a uma latitude $01^{\circ} 58^{\prime} 30^{\prime \prime}$ sul e a uma longitude $48^{\circ} 57^{\prime} 35^{\prime \prime}$ oeste, estando a uma altitude de 17 metros, com uma área de aproximadamente 1.996,790 km², dista $78 \mathrm{~km}$ de Belém, a capital do Estado (Figura 1). De acordo com Ibge (2020), o município possui uma população estimada em 62.698 habitantes, com uma densidade demográfica de 29,08 hab/ $/ \mathrm{km}^{2}$. Limitase ao Norte com o município de Abaetetuba; a Leste com Moju; ao Sul com Cametá e Moju e a Oeste com Cametá e Limoeiro do Ajurú (Idesp, 2011).

Figura 1: Localização do município de Igarapé-Miri, Estado do Pará.

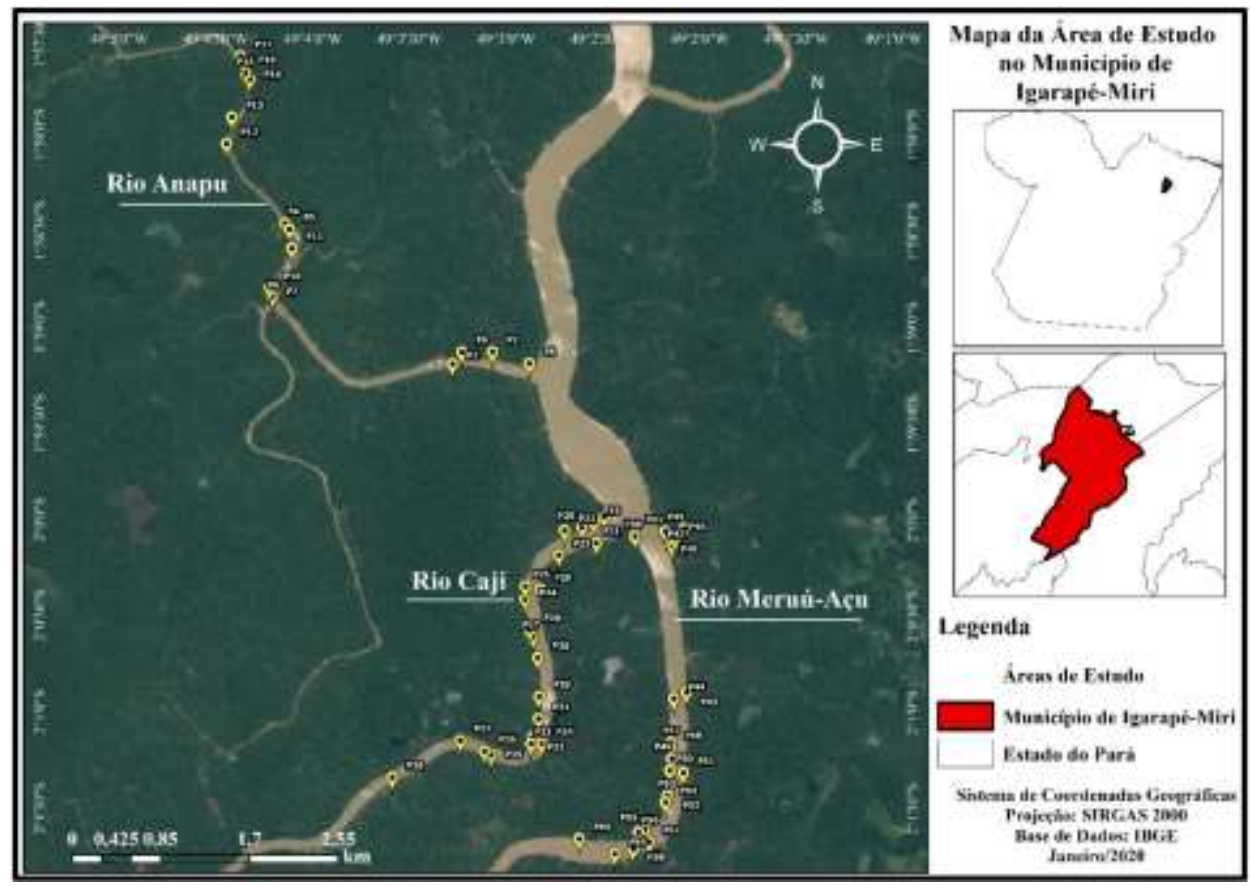

*Os pontos marcados referem-se aos produtores entrevistados. Fonte: Dados da pesquisa (2019).

Os locais da coleta de dados correspondentes a três comunidades apresentam as seguintes coordenadas geográficas:

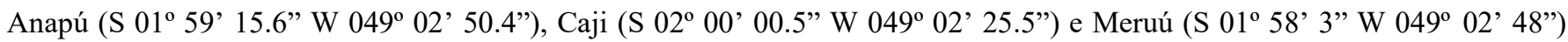


(Figura 1). O acesso às comunidades se dá por via fluvial, em embarcações de médio e pequeno porte com duração de 1:30 à 2:00 horas, a depender do tipo de embarcação, maré e das condições climáticas.

A área de várzea do município está situada no estuário do rio Amazonas, que se estende do rio Xingu até a costa Atlântica, compreendendo o amplo espectro das várzeas da costa do rio Pará e de toda a região do delta do rio Amazonas (REIS, 2008). O território é composto por áreas de várzea (ilhas) e terras firmes, caracterizadas por uma extensa relação da população com o meio natural (Silva \& Amorim, 2017).

\subsection{Amostragem}

A população alvo do estudo foi composta por famílias ribeirinhas que trabalham com produção de açaí manejado. Para encontrá-las, houve inicialmente, na cidade de Igarapé-Miri, contato com as lideranças dos produtores, Sindicato dos Produtores Rurais de Igarapé-Miri, Secretaria de Estado de Meio Ambiente e Sustentabilidade (SEMAS) do município que indicaram quais comunidades rurais seriam recomendadas para realização do estudo, conforme o objetivo pretendido.

A seleção dos participantes foi por amostragem intencional ou julgamento, considerando os maiores produtores de açaí de cada comunidade, bem como aqueles que fornecem o fruto para outras localidades como Belém e Castanhal. De acordo Lakatos e Marconi (2010), a amostra intencional é a mais comum entre as não-probabilísticas e consiste na escolha dos elementos da amostra por um especialista no assunto, que seleciona os elementos que julga os mais apropriados e representativos para o estudo em questão. Além da caminhada transversal que consiste em percorrer uma determinada área, acompanhado de informantes locais e que conheçam bastante a região (Rocha et al., 2015).

\subsection{Coleta e Análise dos Dados}

Com a seleção e concessão dos produtores para participação na pesquisa, aplicou-se um questionário piloto, em 10 de junho de 2019, para testar as perguntas e assim realizar as possíveis mudanças.

A pesquisa foi conduzida nas comunidades Anapú; Caji e Meruú no período compreendido entre 23 de julho a 9 de agosto de 2019. Para tanto, foram realizadas entrevistas com a aplicação de 61 questionários semiestruturados aos produtores e consumidores de açaí, sendo 17 questionários aplicados na comunidade ribeirinha de Anapú, 21 em Caji e 23 no Meruú.

O tamanho da amostra de 61 produtores foi baseado em outros trabalhos, também, realizados em áreas de várzea que adotaram de 30 a 60 devido ser uma área extensa e de difícil acesso.

Aguiar (2016), em sua pesquisa sobre manejo de açaizeiro no município de Cametá, entrevistou 6 produtores. Soares (2008), em seu estudo sobre os efeitos da demanda crescente de produtos extrativos para os pequenos produtores de açaí na microrregião de Cametá, entrevistou 30 famílias. Martinot et al. (2017), em seu levantamento no baixo rio Manacapuru (Amazonas) aplicou o questionário a 30 famílias que trabalham com açaí. Souza (2019), no seu estudo no município de Feijó (Acre) entrevistou 42. Araújo e Navegantes-Alves (2015), em seu estudo sobre o sistema de manejo no município de IgarapéMiri, aplicou 52 questionários aos ribeirinhos. Silva Júnior (2019), em seu estudo de caso com produtores de açaí no município de Igarapé-Miri aplicou 52 questionários. Germano et al. (2014) em seu levantamento em Abaetetuba entrevistou 63 ribeirinhos.

Para caracterizar os aspectos socioeconômicos, as questões pertinentes do questionário foram: gênero, idade, naturalidade, estado civil, tempo de residência no local, composição familiar, escolaridade, fonte principal e secundária de renda da família, situação fundiária, aspectos produtivos, manejo, colheita e comercialização.

Após a coleta de dados, os mesmos foram submetidos a tratamentos estatísticos por meio dos softwares Excel 2010. 


\section{Resultados e Discussão}

A partir do levantamento socioeconômico realizado nas comunidades ribeirinhas foram analisados os dados de maior importância com o intuito de caracterizar o perfil dos ribeirinhos, bem como dos aspectos produtivos.

\subsection{Caracterização dos Produtores}

Nas comunidades rurais de Anapú, Caji e Meruú foram entrevistados 61produtores ribeirinhos, totalizando 285 pessoas envolvendo os familiares. No que se refere aos produtores entrevistados o sexo masculino sobressaiu o feminino, o que representa 91,80\% e 8,20\%, respectivamente (Figura 2). Farias (2012), em seu estudo também apresentou o número de homens maior do que as mulheres nas atividades de manejo de açaizeiro. A predominância do sexo masculino em relação ao feminino pode ser explicada, por uma maior demanda de mão de obra masculina em atividades agroextrativistas e por conta de que muitas mulheres acabam saindo da zona rural para trabalhar em casas de família em áreas urbanas (Silva et al., 2016a).

Figura 2: Gênero, idade, estado civil, tempo de moradia e escolaridade dos produtores de açaí das comunidades Anapú, Meruú e Caji

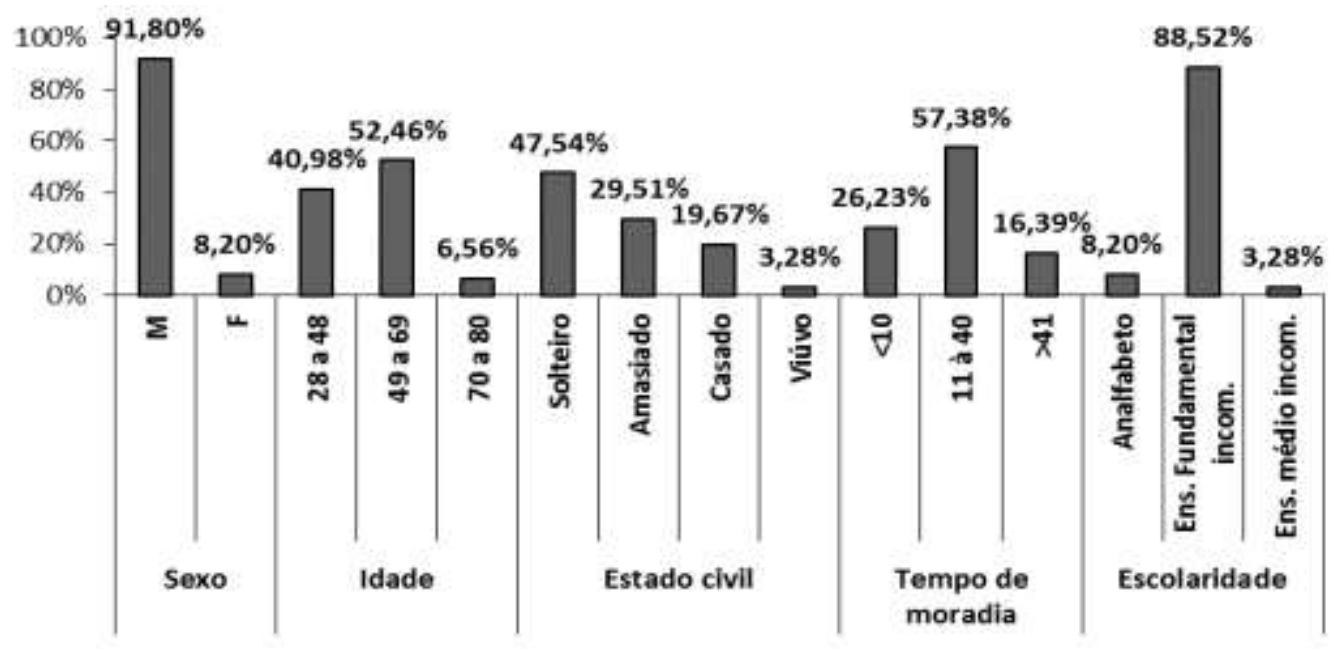

Fonte: Dados da pesquisa (2019).

Percebe-se que a faixa etária apresenta variação de 28 a 80 anos, sendo que a idade média dos produtores de 50 anos. A maior parcela (52,46\%) situa-se na faixa de 49 a 69 anos e cerca de 40,98\% possuem entre 49 a 69 anos (Figura 2). Esses resultados assemelham-se com os dados publicados por Souza (2019), no município de Feijó (Acre), em que produtores de açaí possuem idade variando entre 23 e 73 anos com média de 47 anos e a maioria com 50 a 59 anos. A maior parcela (88, 52\%) é natural de comunidades rurais de Igarapé-Miri, tais como: Meruú (31,15\%), Anapú (24,15\%), Caji (19,67\%), Nova União; Riozinho e Vila Maiuatá (13,11\%) e os demais nasceram na cidade de Igarapé-Miri (6,56\%), Abaetetuba, Belém e Vigia com $(1,64 \%)$, respectivamente.

Quanto ao estado civil, foi verificado que $47,54 \%$ dos produtores são solteiros, o restante possui união estável $(29,51 \%)$ e os que são formalmente casados representa 19,67\%. Feio, Girard e Mendonça (2014), em seu estudo relatou situação conjugal similar, pois a maioria dos entrevistados (71\%) eram solteiros, em seguida com $26 \%$ os casados e $2 \%$ os divorciados.

Estas famílias são compostas de 5 membros por unidade familiar, resultado similar encontrado por Arruda (2016). A média do tempo de moradia correspondeu a 27 anos, com 57,38\% reside de 11 a 40 anos nas atuais residências e a minoria 
com 16,39\% possuem mais de 41 anos de habitação nas propriedades rurais, o que evidencia uma baixa mobilidade espaçotemporal destes ribeirinhos, bem como bastante domínio da produção (Figura 2).

Em relação ao nível de instrução, oscila do analfabetismo ao ensino médio incompleto, uma vez que a maioria com $88,52 \%$ apresenta ensino fundamental incompleto, com maior concentração na $1^{\circ}, 2^{\circ}$ e $3^{\circ}$ série. Ao passo que, somente, dois ribeirinhos 3,28\% cursaram até ao $1^{\circ}$ ano do ensino médio. Dados similares foram encontrados por Souza (2019) em seu levantamento no município de Feijó, em que a maioria dos entrevistados tem o nível fundamental $76 \%$. Verifica-se que a escolaridade dos ribeirinhos das comunidades estudadas ainda é baixa, caracterizando uma realidade comum no cenário rural, por ser uma atividade periférica e com pouca capacitação (Figura 2). Segundo Rebello e Homma (2017), o empenho por um desenvolvimento mais sustentável na Amazônia requer iniciativas que proporcione a melhoria do capital humano, social e institucional.

No que concerne à renda, cerca de 54,10\% dos entrevistados apresentam de 1 a 2 salários mínimos mensais e da minoria com 9,84\% gira em torno de 3 a 4 salários mínimos (Figura 3), o que possibilita melhoria da qualidade de vida, bem como melhores condições de adquirir bens duráveis que até então não dispunham, tais como: antena parabólica, bomba de água, celular, TV, DVD, fogão a gás, geladeira, máquina de lavar, máquina de açaí, rabeta ${ }^{1}$ e ventilador. Entre os bens de menor ocorrência, destaca-se o freezer, computador, internet, ar-condicionado, telefone fixo, TV a cabo, lancha e casas localizadas nas cidades de Abaetetuba, Barcarena e Belém, além de veículos automotivos (moto e carro).

A utilização do freezer é com o objetivo de armazenar alimentos tanto para o consumo quanto para venda na comunidade (principalmente frango), uma vez que o comércio alimentício fica no centro urbano (distante das comunidades) o que requer maior custo e tempo, ocasionando despesas adicionais com combustíveis, tornando o processo dispendioso e inexequível. Os ribeirinhos que possuem casa em outras cidades (Belém e Barcarena) deve-se ao fato de que um dos entrevistados possui emprego em Barcarena, permanecendo na mesma durante a semana e aos finais de semana vai para a comunidade onde reside e o ribeirinho que possui casa em Belém, mora na comunidade de Meruú e deixa seus familiares em sua casa de Belém.

Figura 3: Renda e atividade extra dos produtores de açaí das comunidades Anapú, Meruú e Caji.

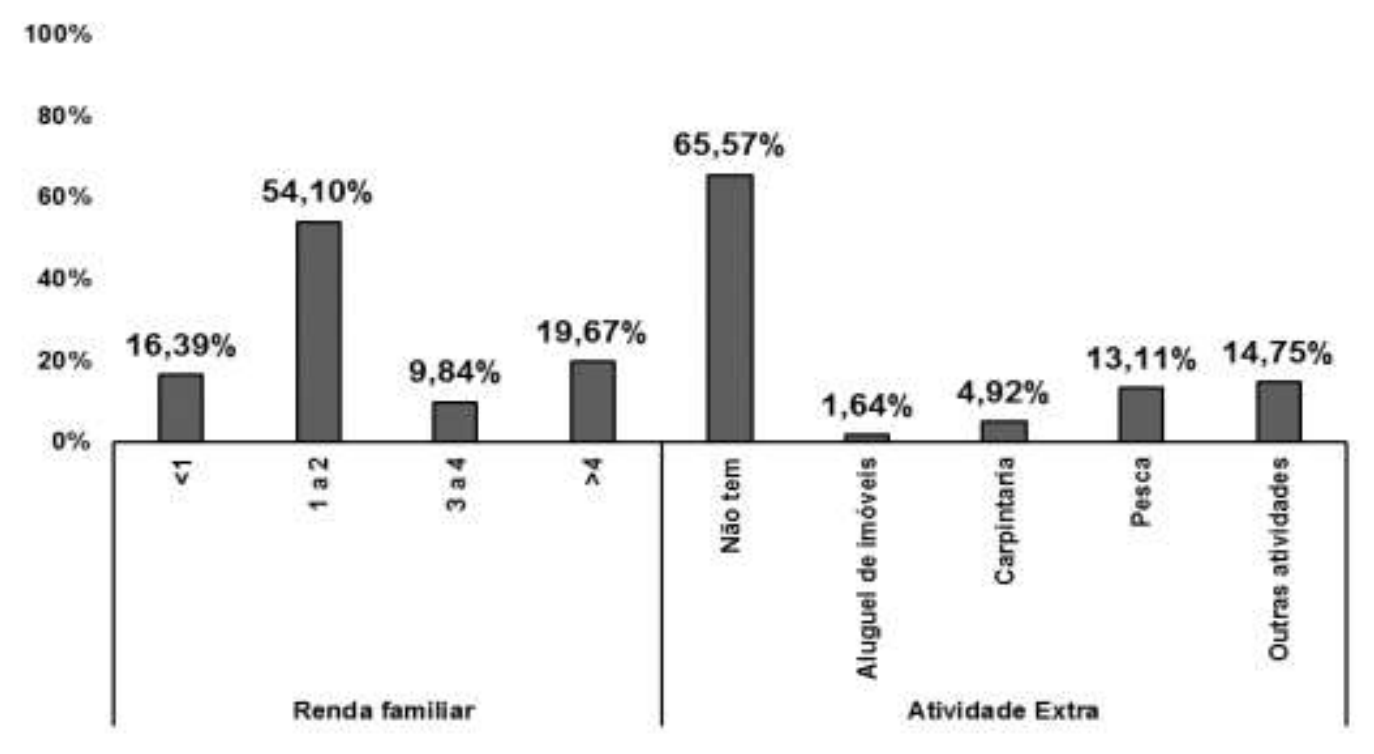

Fonte: Dados da pesquisa (2019).

\footnotetext{
${ }^{1}$ Rabeta é um tipo de barco de menor porte com motor e hélice, considerado o meio de transporte mais utilizado pelos ribeirinhos.
} 
De acordo com Silva et al (2016), a produção do açaí na comunidade Meruú além de ser um recurso gerador de renda, também fortalece a identidade local, bem como é fator incontestável na constituição de um modo de vida que se divide basicamente em função da safra e entressafra do fruto.

Em relação ao desenvolvimento de atividades extras, a maior concentração dos entrevistados 65,57\%, afirmaram não possuir outro ofício além da realização do manejo do açaizeiro. Cerca de 13,11\% e 4,92\% relataram exercer atividades de pesca e carpintaria, respectivamente (Figura 3). Lima (2015), corrobora esse percentual relativo à pesca, pois encontrou resultado similar em seu estudo sobre o modo de vida da população. Souza (2019), em seu estudo constatou que mais da metade têm como principal atividade a própria venda de açaí 55\%, seguido de seringueiro $24 \%$, agricultor $19 \%$ e que trabalham em outro setor $2 \%$. Mesmo a maior parcela dos entrevistados terem como atividade principal, somente, relacionadas ao açaizal, guardando uma parte da renda obtida na safra, para utilizarem na entressafra.

Em relação às transferências governamentais (Tabela 1), percebe-se que a maioria dos ribeirinhos 37,70\% recebe Bolsa Família (programa federal de transferência direta de renda destinado às populações pobres). Uma das características do Bolsa Família é a transferência do benefício financeiro ao acesso a direitos sociais básicos, como saúde, alimentação, educação e assistência social (Bichir, 2010). Cerca de 13,11\% dos entrevistados afirmaram receber aposentadoria e alguns recebem tanto aposentadoria quanto Bolsa Família 9,84\%. Outro auxílio é o seguro defeso com o equivalente a 6,56\%. No entanto, verifica-se que uma parcela não recebe nenhum tipo de auxílio oferecido pelo governo, sendo representados por 32,79\% (Tabela 1).

Tabela 1: Transferências governamentais recebidas pelos ribeirinhos das comunidades Anapú, Meruú e Caji.

\begin{tabular}{lll}
\hline Benefício & Produtores & \% \\
\hline Não recebe & 20 & 32,79 \\
Aposentadoria & 8 & 13,11 \\
Bolsa família & 23 & 37,70 \\
Aposentadoria e Bolsa Família & 6 & 9,84 \\
Seguro defeso & 4 & 6,56 \\
\hline Total & $\mathbf{6 1}$ & $\mathbf{1 0 0 , 0 0}$ \\
\hline
\end{tabular}

Fonte: Dados da pesquisa (2019).

\subsubsection{Infraestrutura e saneamento básico}

Em relação a situação fundiária, 33 produtores equivalente a 54,10\% dos 61 entrevistados, obtiveram a área a partir da herança dos pais, assim como 40,98\% adquiriram por meio de compra e se autointitulavam proprietários e 1,64\% eram arrendatário; parceiro/meeiro e posseiro/ocupante, respectivamente. As casas são localizadas no mesmo lote do terreno de produção de açaí com $96,72 \%$ e os demais possuem a casa localizada na comunidade $3,28 \%$, mas em terreno diferente do açaizal.

Nas comunidades estudadas, predominam casas com parede de madeira 90,16\% com 3 a 4 cômodos. No entanto, 9,84\% dos produtores já possuem casa de alvenaria. Cerca de $81,97 \%$ dos pisos é de madeira e em outras já se encontra piso de lajota $8,20 \%$ e a cobertura de telha de barro $75,41 \%$ é a que prevalece (Tabela 2). Embora a maioria das residências sejam rústicas, as pequenas parcelas de casas de alvenaria e piso de lajota já sinalizam o empenho por uma qualidade superior na infraestrutura de moradia dos ribeirinhos. Aranha (2015), em seu levantamento realizado no município de Igarapé-Miri, verificou que $93 \%$ das casas estão localizadas no lote e 3\% estão na cidade. O piso e parede das casas são de madeira 93\%, 7\% são casas de alvenaria, $3 \%$ têm piso de cimento e 3\% têm piso de chão batido, $97 \%$ têm telhado de barro, e 3\% têm cobertura de palha. 
Tabela 2: Número de cômodos, tipo de parede, piso e cobertura das residências dos ribeirinhos nas comunidades Anapú, Meruú e Caji.

\begin{tabular}{|c|c|c|}
\hline Número de cômodos & Produtores & $\%$ \\
\hline 0 a 2 & 20 & 32,79 \\
\hline 3 a 4 & 36 & 59,02 \\
\hline 5 A 6 & 5 & 8,20 \\
\hline Total & 61 & 100,00 \\
\hline Parede & Produtores & $\%$ \\
\hline Madeira & 55 & 90,16 \\
\hline Alvenaria & 6 & 9,84 \\
\hline Total & 61 & 100,00 \\
\hline Piso & Produtores & $\%$ \\
\hline Cimento & 6 & 9,84 \\
\hline Lajota & 5 & 8,20 \\
\hline Madeira & 50 & 81,97 \\
\hline Total & 61 & 100,00 \\
\hline Cobertura & Produtores & $\%$ \\
\hline Brasilit & 11 & 18,03 \\
\hline Cavaco & 1 & 1,64 \\
\hline Palha & 3 & 4,92 \\
\hline Telha de barro & 46 & 75,41 \\
\hline Total & 61 & 100,00 \\
\hline
\end{tabular}

Fonte: Dados da pesquisa (2019).

Em relação ao saneamento básico, a maioria das casas utilizam como banheiro uma pequena casa de madeira localizada nos fundos. Resultados encontrados por Aranha, Silva e Coelho (2015), em Igarapé-Miri, constatou que $90 \%$ dos banheiros são de madeira situados ao fundo. O esgoto sanitário é ausente na maioria das propriedades rurais visitadas, uma vez que $80,33 \%$ destinam o dejeto sanitário em fossa negra, a fossa de cimento é utilizada por 11,48\% e 8,20\% despeja diretamente no rio (Figura 4). Resultados semelhantes foram obtidos por Silva et al. (2016b), em seu estudo sobre saneamento básico na comunidade rural do Baixo Rio Araguari, mostrou que 70,9\% da comunidade utiliza a fossa negra. Segundo Arruda et al. (2016), fossa negra é um buraco no solo sem nenhuma proteção, onde as fezes são depositadas e com risco de contaminação quando atingem o lençol freático. Para Sabei e Bassetti (2013), a preservação ambiental é uma razão importante para tratar os esgotos, pois as substâncias presentes nesses dejetos exercem ações deletérias nos corpos d'água em que a matéria orgânica pode ocasionar a exaustão do oxigênio dissolvido, resultando na morte de peixes e outros organismos aquáticos, bem como no escurecimento da água e aparecimento de mau odor. 
Figura 4: Despejo sanitário das residências dos ribeirinhos das comunidades Anapú, Caji e Meruú

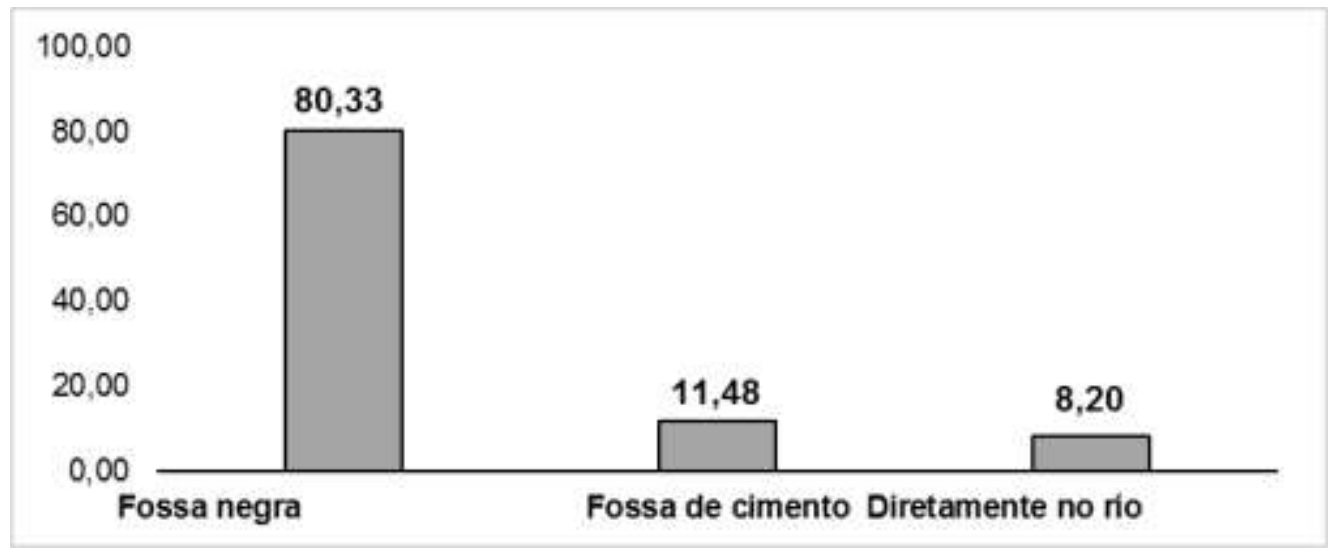

Fonte: Dados da pesquisa (2019).

\subsection{Caracterização do Sistema de Produção}

O levantamento evidenciou que as áreas de produção apresentaram variação de 1 a 98 hectares com média de 12 hectares/família. A maioria dos ribeirinhos 44,26\% possuem áreas de até 5 ha, seguido de 29,51\% dos entrevistados que possuem de 6 a 10 ha e a minoria dos entrevistados 11,48\% com até 98 hectares (Figura 5). Tagore (2017), em seu estudo sobre o aumento da demanda do açaí em Abaetetuba, verificou que 39\% dos ribeirinhos possuem área de 5 a 10 hectares e $30 \%$ até 5 hectares.

Figura 5: Área (ha) ocupada com açaizeiros dos ribeirinhos das comunidades Anapú, Caji e Meruú.

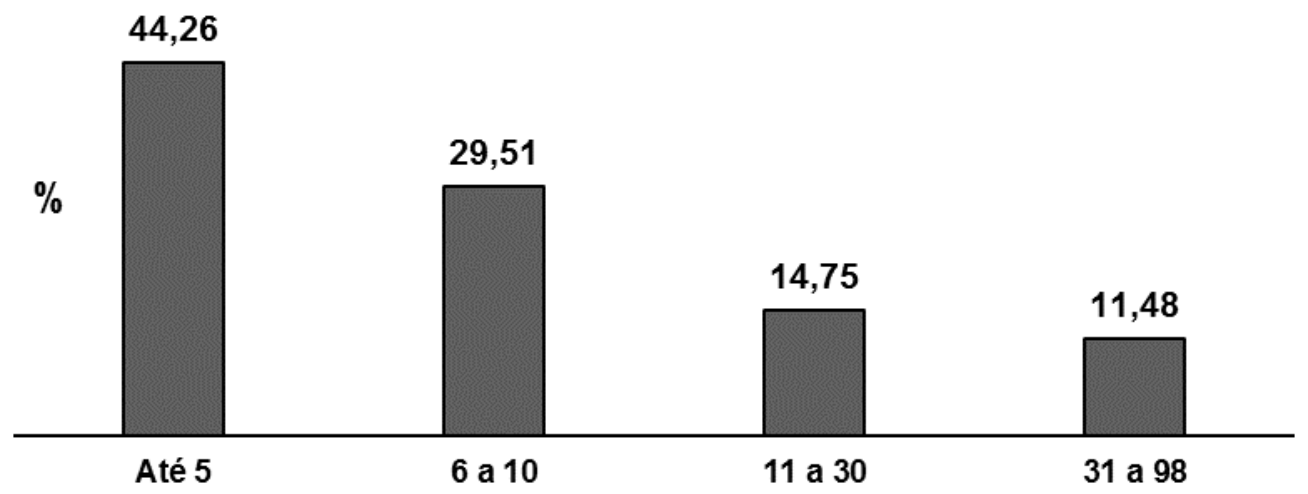

Fonte: Dados da pesquisa (2019).

O sistema de manejo é praticado por todos os produtores entrevistados das comunidades Anapú, Caji e Meruú, com o intuito de aumentar a produção. As práticas de manejo mais adotadas são o desbaste (retirada dos estipes de açaizeiros excedentes das touceiras, assim como plantas de outras espécies de menor interesse econômico com o objetivo de diminuir a concorrência) e a limpeza (realização da roçagem para controle e eliminação de espécies invasoras). O cultivo de açaizeiro, sendo a principal atividade econômica tem como manejo a limpeza da área, onde o agricultor realiza a roçagem, coroamento e limpeza dos estipes, além da recoberta do solo através de cobertura morta, realizando assim, a incorporação de matéria orgânica, sendo essa a principal fonte de adubação, uma vez que não se utiliza adubação química (Aranha; Silva e Coelho, 2015).

O cultivo de açaizeiro em várzeas, por meio de plantios em áreas desflorestadas sem queima, de manejo e de enriquecimento florestal, em associação com outras espécies frutíferas e florestas adaptadas a essas condições, deve ser 
estimulado e considerado como uma das alternativas para transformar as áreas ribeirinhas mais produtivas e ecologicamente melhor protegidas (Nogueira; Homma, 1998). Para Aguiar (2016), o manejo do açaizeiro é um conjunto de técnicas específicas, cujo principal objetivo é aprimorar o cultivo do fruto almejando o aumento da produtividade.

\subsubsection{Produção}

A aferição da produção de açaí por ribeirinhos é complexa, pois os mesmos não realizam anotações e não contabilizam, uma vez que nota fiscal não é emitida em nenhum processo da cadeia produtiva, configurando-se em uma economia invisível. Estudo realizado por Menezes (2002) no Projeto de Assentamento Agroextrativista Praialta e Piranheira no município de Nova Ipixuna verificou que $18,77 \%$ da renda dos produtores familiares venham da produção invisível.

Tabela 3: Produção (kg) nas comunidades Anapú, Meruú e Caji.

\begin{tabular}{lll}
\hline Período & Produção Total & Produção por família \\
\hline Safra & $1.356 .555,04$ & $22.238,61$ \\
Entressafra & $847.983,88$ & $13.901,38$ \\
\hline Total & $\mathbf{2 . 2 0 4 . 5 3 8 , 9 2}$ & $\mathbf{3 6 . 1 3 9 , 9 8}$ \\
\hline
\end{tabular}

Fonte: Dados da pesquisa (2019).

Verificou-se que a produção anual nas três comunidades rurais analisadas foi de $2.204 .538,92 \mathrm{~kg}$. Observa-se que a produção por família foi de $36.139,98 \mathrm{~kg}$. A produtividade total foi de $3.013,90 \mathrm{~kg} / \mathrm{ha}$. Vale ressaltar que o açaí consumido pelos ribeirinhos representa $16 \%$ da produção total, sendo $10 \%$ da safra e $6 \%$ da entressafra. Portando, a falta de anotações dos dados relativos à produção nas comunidades ribeirinhas prejudica a aferição dos dados. Desse modo, faz-se necessário um acompanhamento periódico com a realização de mais visitas.

Menezes (2002), considera que a produção agrícola e extrativa, é muito superior à que vem sendo apresentada pelas estatísticas oficiais, pois existe uma economia invisível, incluindo a produção consumida no núcleo familiar.

\subsubsection{Safra}

Quanto à produção de frutos, há duas épocas diferentes nas áreas de várzea do estuário amazônico conhecidas como safra e entressafra. Segundo Aguiar (2016), na safra, a produção do açaí aumenta bastante e os cachos e frutos apresentam tamanhos semelhantes com coloração vermelho-arroxeada, sendo considerado de qualidade superior e o ideal para a colheita. Os ribeirinhos dedicam-se ao trabalho da colheita e da comercialização do produto, sendo considerado o período da abundância em que ocorre o planejamento da reforma da casa e a aquisição de bens materiais (Lima \& Silva, 2014). 
Figura 6: Mês de maior produção de açaí durante a safra nas comunidades Anapú, Caji e Meruú.

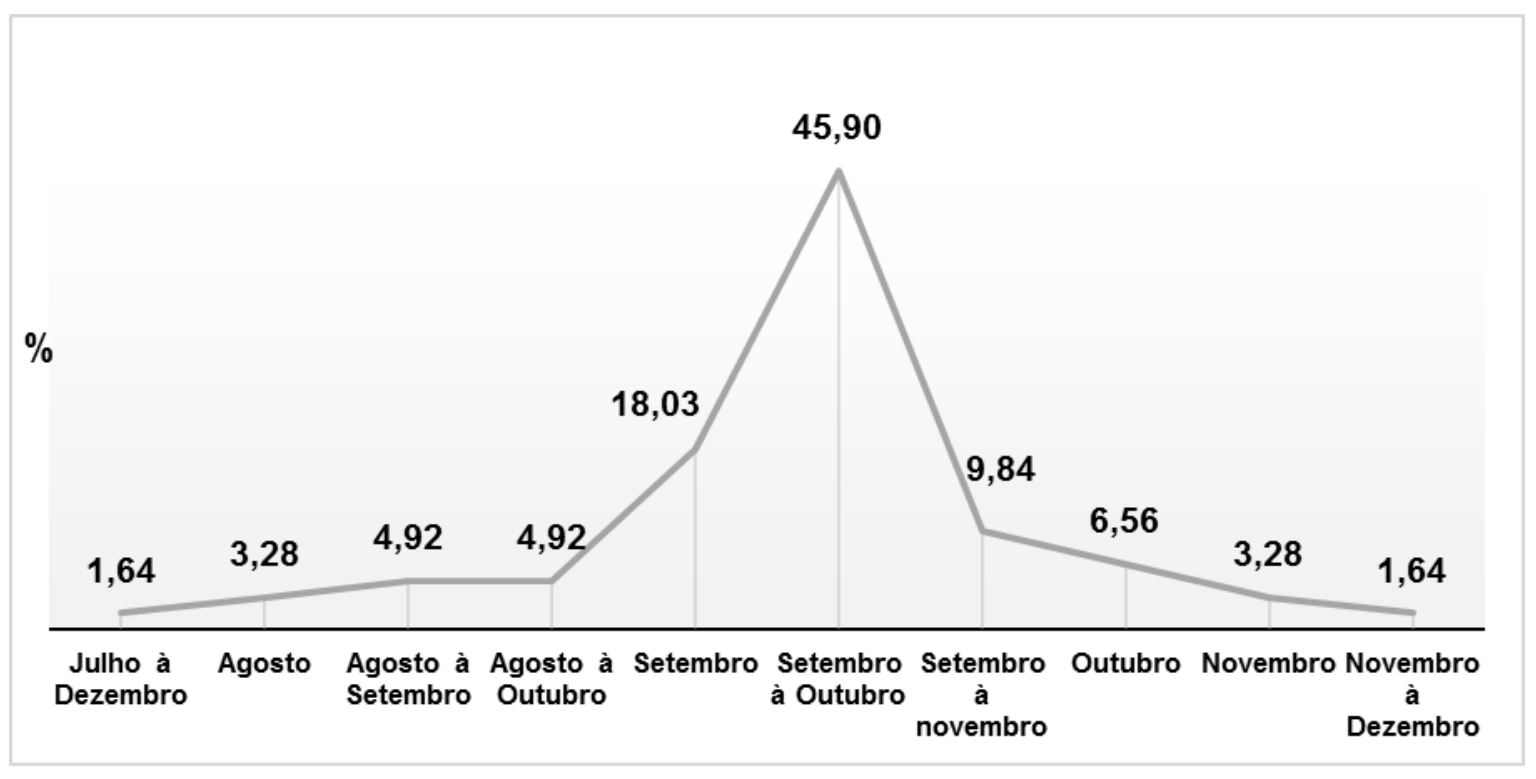

Fonte: Dados da pesquisa (2019).

Os resultados da pesquisa de campo demonstraram que, nas comunidades estudadas, a safra possui duração de 6 meses (julho a dezembro), período em que a renda dos ribeirinhos aumenta com a venda do fruto. Os entrevistados quando perguntados sobre o mês de maior produção, cerca de 45,90\% responderam ser setembro a outubro (Figura 6). A produção se concentra no mês de julho a janeiro, sendo mais intensa nos meses de setembro a novembro, quando esta é substancialmente maior, com preços relativamente baixos (Santos, 2018).

Durante esse intervalo, o preço da rasa de açaí apresenta variações, oscilando de $\mathrm{R} \$ 18,00$ até $\mathrm{R} \$ 60,00$. A média de preço de uma rasa de $14 \mathrm{~kg}$ é de $\mathrm{R} \$ 40,09$ e cerca $65,57 \%$ dos entrevistados comercializam a rasa por $\mathrm{R} \$ 18,00$ a $\mathrm{R} \$ 40,00$, sendo que o valor de $\mathrm{R} \$ 40,00$ e $\mathrm{R} \$ 50,00$ são os mais recorrentes (Tabela 3). Nogueira e Santana (2009), em sua análise da sazonalidade dos preços do açaí no estado do Pará, observaram que o açaí na safra, período compreendido entre agosto a janeiro, apresenta índice de preço abaixo da média, devido ao excesso de oferta do produto no mercado.

Tabela 4: Preço da rasa de açaí no período da Safra nas comunidades Anapú, Meruú e Caji.

\begin{tabular}{lll}
\hline Preço $(\mathbf{R} \$)$ & Produtores & \% \\
\hline 18 a 40 & 40 & 65,57 \\
41 a 60 & 21 & 34,43 \\
\hline $\mathbf{1 0 0}$ & $\mathbf{6 1}$ & $\mathbf{1 0 0 , 0 0}$ \\
\hline
\end{tabular}

Fonte: Dados da pesquisa (2019).

Os entrevistados relataram ganhar na safra um montante de $\mathrm{R} \$ 3.000,00$ a $\mathrm{R} \$ 180.000,00$ com uma média de $\mathrm{R} \$ 27.000,00$, o que auxilia na obtenção de bens duráveis, assim como na reserva de dinheiro para usar na entressafra e para realização da limpeza anual das áreas. Desse modo, a média de lucro equivale a $\mathrm{R} \$ 16.000,00$ e a de despesa é $\mathrm{R} \$ 11.000,00$.

\subsubsection{Entressafra}

No período da entressafra, a produção do açaí não é totalmente nula, mas diminui bastante e os frutos apresentam-se em diferentes estágios de maturação, sendo considerado um açaí de qualidade inferior (Aguiar, 2016). Os ribeirinhos adotam 
diferentes estratégias para sobreviverem e cada família busca a melhor forma de se manter. Pequenas criações de animais, a caça (esta atividade segundo relatos de moradores é cada vez menos praticada devido à escassez do que se caçar), trabalhos temporários como a carpintaria, pesca, são as principais atividades para aumentar a renda para ajudar na alimentação ou em pequena escala para o comércio como acontece com o camarão (Lima e Silva, 2014).

$\mathrm{Na}$ entressafra, mesmo tendo menor oferta do fruto, cerca de $91,80 \%$ afirmaram vender açaí, os demais $8,20 \%$ não comercializam, pois, a quantidade produzida é ínfima, tendo-se disponível somente para o autoconsumo (Tabela 5).

Tabela 5: Venda de açaí na entressafra nas comunidades Anapú, Meruú e Caji.

\begin{tabular}{lll}
\hline Venda na Entressafra & Produtores & $\%$ \\
\hline Sim & 56 & 91,80 \\
Não & 5 & 8,20 \\
\hline Total & $\mathbf{6 1}$ & $\mathbf{1 0 0 , 0 0}$ \\
\hline
\end{tabular}

Fonte: Dados da pesquisa (2019).

O período de menor oferta do fruto ocorre em seis meses (janeiro a junho), sendo que março a abril 24,59\% é considerado o intervalo de tempo em que a produção é ainda menor e/ou inexistente, conforme mostra a figura a seguir:

Figura 7: Mês que não dispõe da produção de açaí no período da entressafra nas comunidades Anapú, Caji e Meruú.

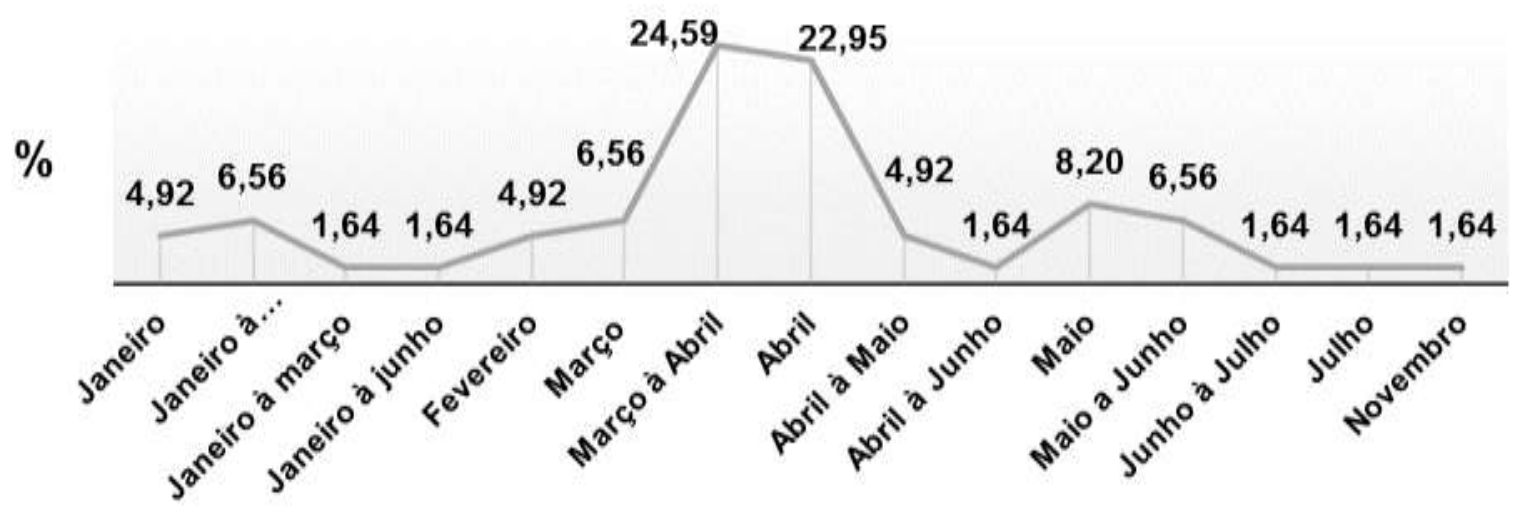

Fonte: Dados da pesquisa (2019).

Logo, entre janeiro a junho a produção reduz drasticamente. No entanto, o pouco produzido ainda possibilita uma comercialização (mesmo que pouco expressiva quando comparada com a safra), o que influência no preço da rasa vendida. $\mathrm{Na}$ entressafra, o preço do produto se eleva significativamente, em decorrência da escassez de oferta do produto no mercado (Nogueira, 2009). 
Tabela 6: Preço da rasa de açaí no período da entressafra nas comunidades Anapú, Meruú e Caji.

\begin{tabular}{lll}
\hline Preço (Entressafra) & Produtores & $\%$ \\
\hline Não vende & 5 & 8,20 \\
$\mathrm{R} \$ 50,00$ a R $\$ 70,00$ & 4 & 6,56 \\
$\mathrm{R} \$ 71,00$ a R $\$ 90,00$ & 15 & 24,59 \\
$\mathrm{R} \$ 91,00$ a R $\$ 110,00$ & 23 & 37,70 \\
$\mathrm{R} \$ 111,00$ a R $\$ 165,00$ & 14 & 22,95 \\
\hline TOTAL & $\mathbf{6 1}$ & $\mathbf{1 0 0 , 0 0}$ \\
\hline
\end{tabular}

Fonte: Dados da pesquisa (2019).

$\mathrm{Na}$ entressafra, o preço da rasa apresenta uma variação de $\mathrm{R} \$ 50,00$ a $\mathrm{R} \$ 165,00$, com média de $\mathrm{R} \$ 93,53$. A maioria dos entrevistados $37,70 \%$ comercializam a rasa por $R \$ 91,00$ a $R \$ 110,00$ e cerca de $22,95 \%$ por $R \$ 111,00$ a $R \$ 165,00$. O valor médio que eles ganham é de $\mathrm{R} \$ 5.000,00$, variando de $\mathrm{R} \$ 1.000,00$ a $\mathrm{R} \$ 30.000,00$, sendo $\mathrm{R} \$ 3.000,00$ o equivalente ao lucro de $\mathrm{R} \$ 2.000,00$ de despesa.

Portanto, na safra a disponibilidade do fruto é maior, o que influencia no preço do produto. Embora, a produção na entressafra seja inferior ao da safra, o preço da comercialização da rasa é substancialmente maior. Essa variação indica que o comportamento dos preços é instável, sendo informações de suma importância para nortear políticas públicas com o intuito de ampliar a oferta e ordenar a comercialização.

\subsubsection{Colheita}

A colheita dos cachos é realizada no período da manhã, geralmente de 6:00 às 11:00 horas. No entanto, 26,23\% efetuam a colheita no período da tarde no horário de 15:00 às 17:00 horas. O horário da realização da colheita está em consonância ao recomendado por Aguiar (2016), em que o mesmo enfatiza a necessidade desse procedimento ser executado nas horas com brisas mais amenas do dia (pela manhã e de tardezinha) para evitar a perda excessiva de água e a fermentação dos frutos. De acordo com Jordão et al. (2016), o ideal é não expor os frutos ao sol para que não ocorra perda excessiva de água, ocasionando entraves no processo de despolpamento, menor rendimento da polpa e coloração fora do padrão.

O pagamento dos trabalhadores que realizam a colheita chamado de "peconheiro" é efetuado em dinheiro, em que na safra, o preço por cada rasa colhida apresenta uma variação de $\mathrm{R} \$ 15,00$ a $\mathrm{R}$ \$ 20,00 e na entressafra esse serviço geralmente é realizado pelos próprios produtores e seus familiares, uma vez que a quantidade colhida é inferior.

Tabela 7: Tipo de mão de obra contratada nas comunidades Anapú, Meruú e Caji.

\begin{tabular}{lll}
\hline Tipo de mão de obra contratada & Produtores & \% \\
\hline Seca & 32 & 52,46 \\
Molhada & 23 & 37,70 \\
Seca e molhada & 6 & 9,84 \\
\hline Total & $\mathbf{6 1}$ & $\mathbf{1 0 0 , 0 0}$ \\
\hline
\end{tabular}

Fonte: Dados da pesquisa (2019). 
Os trabalhadores contratados tanto para realização das atividades de manejo quanto para a colheita, a maioria 52,46\% é do tipo seca, ou seja, o produtor não fornece alimento, enquanto que $37,70 \%$ fornece refeição e cerca de 9,84\% é do tipo seca e molhada (as vezes disponibiliza refeição e em outros casos, o trabalhador é o responsável por levar ou realiza as refeições em suas próprias residências). A provisão de refeições aos trabalhadores, em alguns casos, é descontada do pagamento do serviço, ou seja, aqueles que realizam as refeições nas casas dos produtores geralmente recebem um valor menor do que os que levam alimentação e/ou almoçam em suas moradias.

Para a realização da colheita, o trabalhador escalona o açaizeiro com o auxílio de um instrumento denominado peconha (laço colocado nos pés com o intuito de facilitar a subida), assim como o terçado ou faca para efetuar o corte do cacho que necessita ser deslocado junto para impedir a perda do fruto. Os entrevistados relataram que são utilizados diferentes tipos de peconha fabricados com diversos materiais, como mostra a Figura 8:

Figura 8: Tipos de peconhas utilizadas na colheita nas comunidades Anapú, Caji e Meruú.

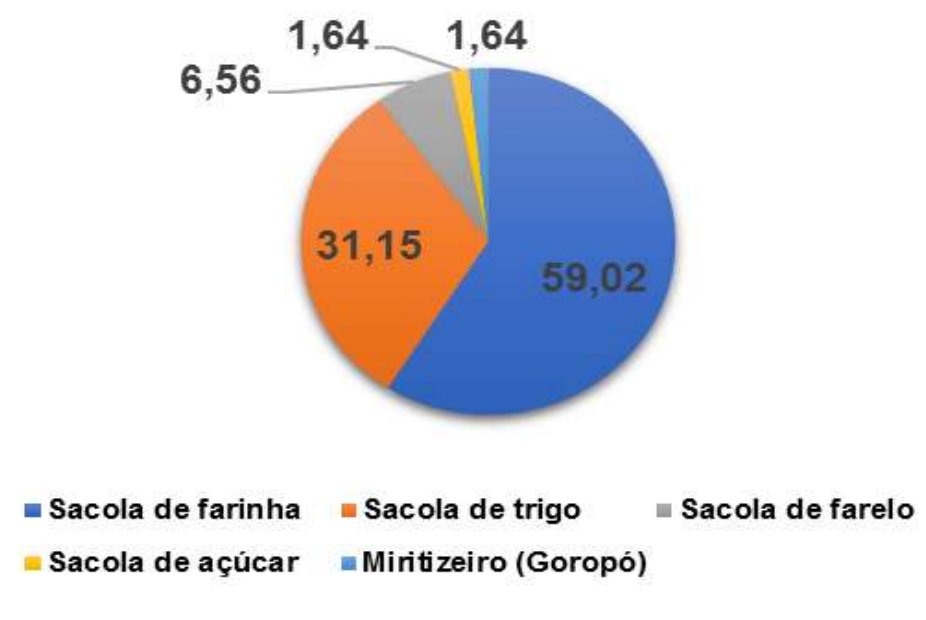

Fonte: Dados da pesquisa (2019).

A peconha produzida com sacola de farinha apresenta maior representatividade com 59,02\% com até 2 semanas de durabilidade, as fabricadas com material de sacola de trigo correspondem a 31,15\%, a qual mantem-se em boas condições de uso por até 3 dias, cerca de 6,56\% são de sacola de farelo a qual mantem-se em bom estado por até 2 dias. As de sacola de açúcar e as de folha de miritizeiro (Mauritia flexuosa) são as menos usadas com 1,64\%, respectivamente, com duração de um dia (Figura 8).

A debulha consiste na retirada do fruto do cacho, é realizada em baixo do açaizeiro ou em um local da área. Os resultados demonstram que esse procedimento é feito direto no chão por $36,07 \%$ dos entrevistados, cerca de $34,43 \%$ conduz sobre plástico, a lona também é utilizada por $22,95 \%$ e a utilização da folha de açaí representa 6,56\% (Tabela 8). 
Tabela 8: Debulha nas comunidades Anapú, Meruú e Caji.

\begin{tabular}{lll}
\hline Debulha & Produtores & $\%$ \\
\hline Plástico & 21 & 34,43 \\
Lona & 14 & 22,95 \\
Direto no chão & 22 & 36,07 \\
Folhas de açaí & 4 & 6,56 \\
\hline Total & $\mathbf{6 1}$ & $\mathbf{1 0 0 , 0 0}$ \\
\hline
\end{tabular}

Fonte: Dados da pesquisa (2019).

Os frutos são acondicionados em rasas de arumã (Ischinasiphon obliquus (Rud.) Koern (88,52\%), sendo posteriormente transferidos para basquetas de plástico (caixa) do atravessador, no momento do transporte. Cerca de 6,56\% dos entrevistados já realizam a debulha diretamente em basquetas, cedidas pelos compradores, maximizando o processo de venda. Os demais 4,92\% acondicionam em rasas de fitas, que são produzidas por eles próprios ou compradas nas comunidades. Os dados estão em consonância ao relatado por Homma et al. (2006), em que após a colheita os frutos são acondicionados em cestos fabricados com fibras de arumã, com capacidade para suportar 14 ou $28 \mathrm{~kg}$ de frutos. Os cestos ou rasas proporcionam aeração. Porém, ocasiona danos mecânicos devido ao empilhamento durante o transporte para a comercialização. As caixas de plástico além de facilitar a aeração, são fáceis de higienizar, resistentes e protegem contra os danos mecânicos.

\subsubsection{Comercialização}

Os resultados da pesquisa apontam que $75,41 \%$ dos produtores comercializam a sua produção no trapiche (porto localizado na frente da casa do produtor), diretamente para o atravessador e os demais $24,59 \%$, comercializam no trapiche no verão e no inverno optam por vender na feira do açaí localizada no centro do município (Figura 9).

Figura 9: Comercialização do açaí produzido nas comunidades Anapú, Caji e Meruú.

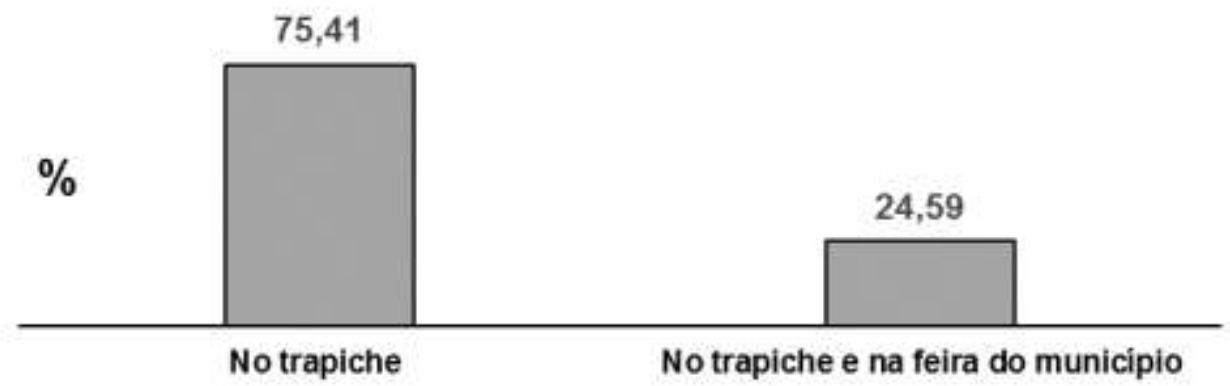

Fonte: Dados da pesquisa (2019).

A venda na cidade é justificada por um maior pagamento pela rasa, principalmente no inverno. No entanto, os que comercializam somente na própria comunidade, alegam a predominância dessa prática devido a comercialização na cidade não recompensar a despesa com combustível, além do tempo gasto para o deslocamento até o centro de Igarapé-Miri. 


\section{Considerações Finais}

Os ribeirinhos das comunidades rurais Anapú, Caji e Meruú possuem, em média, 50 anos, sendo nativos em grande parte das próprias comunidades estudadas, com predomínio do sexo masculino, estado civil solteiro e com tempo de moradia superior a 40 anos (o maior tempo encontrado foi de 74 anos). A herança das áreas advinda dos pais é um fator que explica a permanência nessas localidades e a baixa mobilidade espaço-temporal, assim como grande conhecimento sobre manejo e produção de açaí. A escolaridade é baixa, uma vez que a maioria estudou até o ensino fundamental incompleto e alguns são analfabetos.

A renda gira em torno de 1 a 2 salários mínimos mensais para a maioria e uma pequena parcela com 3 a 4 . Em relação aos bens duráveis, predominam nas residências TV, celular, antena parabólica, geladeira, máquina de beneficiar açaí e fogão a gás. No entanto, os de menor ocorrência foram freezer, computador, ar-condicionado, TV a cabo e lancha. Quanto ao desenvolvimento de atividades extras, verificou-se que a maioria não possui outro trabalho além do açaizal, mas os demais exercem funções relacionadas a carpintaria, pesca, aluguel de imóveis e venda de lanches. As transferências governamentais mais recebidas são do Programa Bolsa Família e Aposentadoria, somado a isso, alguns também afirmaram receber seguro defeso.

A maioria das casas são de madeira com telha de barro ou palha e uma pequena parcela reside em casas de alvenaria com piso de lajota ou casas de madeira com piso de lajota, possuindo 3 a 4 cômodos. Quanto ao saneamento domiciliar, a maioria das famílias necessitam de melhorias sanitárias, pois os banheiros são de madeira localizados no quintal sem esgoto sanitário, sendo os dejetos lançados em fossa negra e/ou diretamente no rio. O que acarreta problemas ambientais afetando tanto o solo quanto os recursos hídricos.

No que concerne ao sistema de produção, percebe-se que a área média ocupada com açaizeiro equivale a 12 hectares/família, em que todos realizam o sistema de manejo com atividades de desbaste e limpeza, obtendo uma produtividade média de 3.013,90 kg por hectare. A adoção do sistema de manejo é praticada com o intuito de alavancar a produção e atender a grande procura por esse fruto. No entanto, esse aumento da demanda acarreta mudanças nas paisagens rurais, uma vez que as mesmas estão cada vez mais se tornando em áreas homogêneas de monocultivos de açaizeiros.

Nos meses de julho a dezembro ocorre a safra, período em que os ribeirinhos adquirem maior renda advinda a partir da comercialização do açaí, principalmente em setembro e outubro, considerado o pico da safra. De janeiro a junho ocorre a entressafra e mesmo com o decréscimo da produção, a maioria dos produtores realizam a comercialização do fruto e com um preço maior, devido a menor oferta de frutos. Na safra, o preço da rasa comercializada varia de $\mathrm{R} \$ 18,00$ até $\mathrm{R} \$ 60,00$, com média de $\mathrm{R} \$ 40,09$, obtendo lucro de $\mathrm{R} \$ 16.000,00$ e $\mathrm{R} \$ 11.000,00$ de despesa, em média. Enquanto que na entressafra esse preço é superior, pois apresenta oscilação de $\mathrm{R} \$ 50,00$ a $\mathrm{R} \$ 165,00$, com média de $\mathrm{R} \$ 93,53$, alcançando em média $\mathrm{R} \$ 3.000,00$ de lucro e R $\$ 2.000,00$ de despesa.

A colheita é realizada mais no período da manhã pelo peconheiro que ganha, em média, $\mathrm{R} \$ 15,00$ a $\mathrm{R} \$ 20,00$ por rasa colhida. Já na entressafra, os produtores são quem realizam essa tarefa devido à produção ser relativamente menor. A maioria desses trabalhadores que executam atividades relacionadas à colheita e limpeza da área, são os responsáveis por levar seu próprio alimento, o que configura a preponderância de mão de obra seca e os demais realizam as refeições na casa dos produtores, caracterizando a mão de obra do tipo molhada.

Entre as peconhas utilizadas para subir no açaizeiro no momento da colheita do fruto, a mais utilizada é produzida a partir de sacola de farinha e a minoria é de sacola de açúcar e folhas de miritizeiro. A debulha do fruto é realizada diretamente no chão ou em cima de plástico, acondicionados em rasas ou caixas de plástico (basqueta). Em seguida, os frutos são transportados até o trapiche para realização da comercialização para os atravessadores e no inverno uma pequena parcela opta por comercializar na feira do açaí localizada no centro da cidade de Igarapé-Miri. 
Em virtude do que foi observado, verifica-se que o açaí é uma cultura de considerável importância na constituição de renda dos ribeirinhos do Baixo Tocantins, auxiliando na obtenção de bens duráveis e na melhoria de condições de moradia. No entanto, essas comunidades carecem de medidas para melhorar e/ou amenizar as condições de saneamento sanitárias rústicas e assim não ocasionar muitos problemas ambientais, para thes proporcionar maior qualidade de vida (bem-estar).

Esses resultados, além de realçar a importância socioeconômica da produção de açaí nas comunidades rurais de Igarapé-Miri, também, são primordiais para nortear o estabelecimento de políticas públicas para fortalecer a cadeia produtiva do açaí no município, adoção de emissão de notas fiscais, bem como despertar a necessidade da realização de mais estudos atrelados a produção dessa cultura.

\section{Agradecimentos}

Aos ribeirinhos das comunidades Anapú, Caji e Meruú, pela disponibilidade de tempo nas entrevistas e informações concedidas. À Secretaria Municipal do Meio Ambiente (SEMMA) e ao Sindicato dos Produtores Rurais de Igarapé-Miri, por todo auxílio proporcionado na realização da pesquisa.

\section{Referências}

Aguiar, A. G. R. (2016). Manejo de população de açaizeiro (Euterpe oleracea Mart.) em parcelas de produção de frutos em área de várzea. Dissertação (PósGraduação em Agriculturas Amazônicas) - Universidade Federal do Pará/Empresa Brasileira de Pesquisa Agropecuária, Belém.

Aranha, A. P. O., Silva, T. F. A., \& Coelho, R. de F. R. (2015). Relato de experiência sobre a agricultura de várzea na comunidade Santo Antônio, município de Igarapé-Miri. Cadernos de Agroecologia, 10(3), 1-5.

Araújo, C. T. D. de \& Navegantes-Alves, L. de F. (2015). Do extrativismo ao cultivo intensivo do açaí (Euterpe oleraceae Mart.) no estuário amazônico: perda de diversidade florística e riscos do monocultivo. Revista Brasileira de Agroecologia, 10(1), 12-23.

Arruda, P. N., Lima, A. S. C., \& Scalize, P. S. (2016). Gestão dos serviços públicos de água e esgoto operados por municípios em Goiás, GO, Brasil. Ambiente \& Água - An Interdisciplinary Journal of Applied Science, 11(2), 362-376.

Bichir, R. M. (2010). O bolsa família na berlinda? os desafios atuais dos programas de transferência de renda. Novos estudos CEBRAP, (87), $115-129$.

Carim, M. J. V. et al. (2014). Análise estrutural de açaizais nativos (Euterpe oleracea Mart.) em Floresta de Várzea, Amapá, Brasil. Biota Amazônia, 4(4), 4551.

Farias, J. E. dos S. (2012). Manejo de açaizais, riqueza florística e uso tradicional de espécies de várzeas do estuário amazônico. Dissertação (Pós-Graduação em Biodiversidade Tropical) - Universidade Federal do Amapá, Macapá.

Feio, V. F., Girard, L., \& Mendonça, N. (2014). Problemática da geração de efluentes oriundos do processamento de açaí na região metropolitana de BelémPA. Revista Monografias Ambientais, 13(3), 3335-3340.

Fundação Amazônia de Amparo a Estudos e Pesquisas (FAPESPA). (2016). Estatísticas municipais paraenses: Igarapé-Miri. Belém: Diretoria de Estatística e de Tecnologia e Gestão da Informação. 61 f.

Germano, C. M., Lucas, F. C. A., Martins, A. C. C. T., Moura, P. H. B. de, \& Lobato, G. de J. M. (2014). Comunidades ribeirinhas e palmeiras no município de Abaetetuba, Pará, Brasil. Scientia Plena, 10(11), 1-10.

Homma, A. K. O., Nogueira, O. L., Menezes, A. J. E. A. de, Carvalho, J. E. U., Nicoli, C. M. L., \& Matos, G. B. de. (2006). Açaí: novos desafios e tendências. Amazônia: ciência \& desenvolvimento, 1(2), 7-23.

Instituto Brasileiro de Geografia e Estatística. Produção Agrícola Municipal (IBGE). (2020). Cidades. 2019. <https://cidades.ibge.gov.br/brasil/pa/igarapemiri/panorama>.

Instituto de Desenvolvimento Econômico, Social e Ambiental do Pará (IDESP). (2011). Estatística municipal: Igarapé-Miri. SEPLAN.

Jordão, M. A., Coelho, R. de F. R., Reis, A. A. dos, \& Nascimento, R. E. N. do. (2016). Vivência e aprendizagem na comunidade Itanambuca no município de Igarapé-Miri - PA. Cadernos de Agroecologia, 10(3).

Lakatos, E. M. \& Marconi, M. de A. (2010). Fundamentos da metodologia científica. Atlas. 
Lakatos, E. M. \& Marconi, M. de A. (2004). Metodologia científica. (4a ed.), Atlas.

Lima, R. S. Na safra e na entressafra do açaí: usos do território e modo de vida da população ribeirinha do baixo Rio Meruú (Igarapé-Miri/PA). (2015). Dissertação (Pós-Graduação em Geografia do Instituto de Filosofia e Ciências Humanas) - Universidade Federal do Pará, Belém.

Lima, R. S. \& Silva, C. N. da. (2014). Territorialidades, paisagem e modo no Baixo Rio Meruú (Igarapé-Miri, Pará). Revista do Instituto Histórico e Geográfico do Pará (IHGP), 1(1), 55-75.

Martinot, J. F., Pereira, H. dos S., \& Silva, S. C. P. da. (2017). Coletar ou cultivar: as escolhas dos produtores de açaí-da-mata (Euterpe precatoria) do Amazonas. Revista de Brasileira de Economia e Sociologia Rural, 55(4), 751-766.

Menezes, A. J. E. A. de. (2002). Análise econômica da "produção invisível” nos estabelecimentos agrícolas familiares no Projeto de Assentamento Agroextrativista Praialta e Piranheira, Município de Nova Ipixuna, Pará. 2002. 130 f. Dissertação (Pós-Graduação em Agriculturas Familiares e Desenvolvimento Sustentável) - Universidade Federal do Pará/ Empresa Brasileira de Pesquisa Agropecuária, Belém.

Nogueira, A. K. M. \& Santana, A. C. de. (2009). Análise de sazonalidade de preços de varejo de açaí, cupuaçu e bacaba no Estado do Pará. Revista de Estudos Sociais, 1(21), 7-22.

Nogueira, O. L. \& Homma, A. K. O. (1998). Análise econômica de sistemas de manejo de açaizais nativos no estuário amazônico. Embrapa-CPATU.

Oliveira, E. A. G. de, Portilho, E. dos S., Menezes, N. S. de, Gomes, B. T. F., Batista, W. C. F., \& Saiter, O. (2007). Ribeirinhos da Amazônia: um relato da vivência no município de Igarapé Miri-Pará. Revista Brasileira de Agroecologia, 2(2), 615-618.

Rebello, F. K. \& Homma, A. K. O. (2017). História da colonização do Nordeste Paraense: uma reflexão para o futuro da Amazônia. Edufra.

Reis, A. A. dos. (2008). Estratégias de desenvolvimento local sustentável da pequena produção familiar na várzea do município de Igarapé-Miri (PA). Dissertação (Pós-Graduação em Desenvolvimento Sustentável do Trópico Úmido) - Universidade Federal do Pará, Belém.

Resque, A. G. L. (2012). Processos de modificação e a sustentabilidade de agroecossistemas familiares na região das Ilhas de Cametá - PA. Dissertação (Pós-Graduação em Agriculturas Familiares e Desenvolvimento Sustentável) - Universidade Federal do Pará, Belém.

Rocha, N. H. N., Bevilacqua, P. D., \& Barletto, M. (2015). Metodologias participativas e educação permanente na formação de agentes comunitários/as de saúde. Trabalho, Educação e Saúde, 13(3), 597-615.

Sabei, T. R. \& Bassetti, F. de J. (2013). Alternativas ecoeficientes para tratamento de efluentes em comunidades rurais. Fórum Ambiental da Alta Paulista, 9 (11), 487-503.

Santos, A. B. (2018). A produção de frutos de açaí (Euterpe oleracea M.) em Limoeiro do Ajuru, Pará: desafios e oportunidades para a ação coletiva de comercialização. Dissertação (Pós-Graduação em Meio Ambiente e Desenvolvimento Rural) - Universidade de Brasília.

Silva, B. da \& Amorim, T. S. (2017). A produção, venda e renda do açaí: um estudo no município de Igarapé-Miri /PA. In: Simpósio Internacional de Geografia Agrária, 8, 2017, Curitiba. Anais... Curitiba: SINGA.

Silva, C. N. et al. (2016). Estratégias de sobrevivência na Amazônia paraense: o caso dos moradores do baixo Rio Meruú (Igarapé-Miri/Pará/Brasil). Geosul, Florianópolis, 31(62), 173-191.

Silva, E. B. da, Alves, C. S., \& Portilho, J. C. dos S. (2016). Diagnóstico Participativo de saneamento básico na comunidade rural do Baixo Rio Araguari, Município de Ferreira Gomes-Amapá, Brasil. Biota Amazônia, 6(2), 17-23.

Silva Júnior, J. I. de S. e. (2019). Socioeconomia e qualidade do solo em áreas nativas cultivadas com açaizeiros no Estado do Pará. Dissertação (PósGraduação em Agronomia) - Universidade Federal Rural da Amazônia, Belém.

Sioli, H. (1991). Amazônia: fundamentos da ecologia da maior região de florestas tropicais. Vozes. (3a ed.), 72p.

Soares, L. C. C. (2008). Os efeitos da demanda crescente de produtos extrativos para os pequenos produtores de açaí (Euterpe oleracea Mart.) na microrregião de Cametá - Pará. Dissertação (Pós-Graduação em Planejamento do Desenvolvimento) - Universidade Federal do Pará, Belém.

Souza, M. R. de S., Silva, E. R. da, \& Souza, L. G. de S. e. (2019). Socioeconomics of sellers of pulp and açai fruits in Feijó - Acre. South American Journal of Basic Education, Technical and Technological, 6(2), 712-725.

Tagore, M. de P. B. (2017). O crescimento da demanda do açaí e as alterações sociais, ambientais e econômicas: o caso das áreas de várzea de Abaetetuba, Pará. Dissertação (Pós-Graduação em Gestão dos Recursos Naturais e Desenvolvimento Local na Amazônia) - Universidade Federal do Pará/Empresa Brasileira de Pesquisa Agropecuária, Belém. 